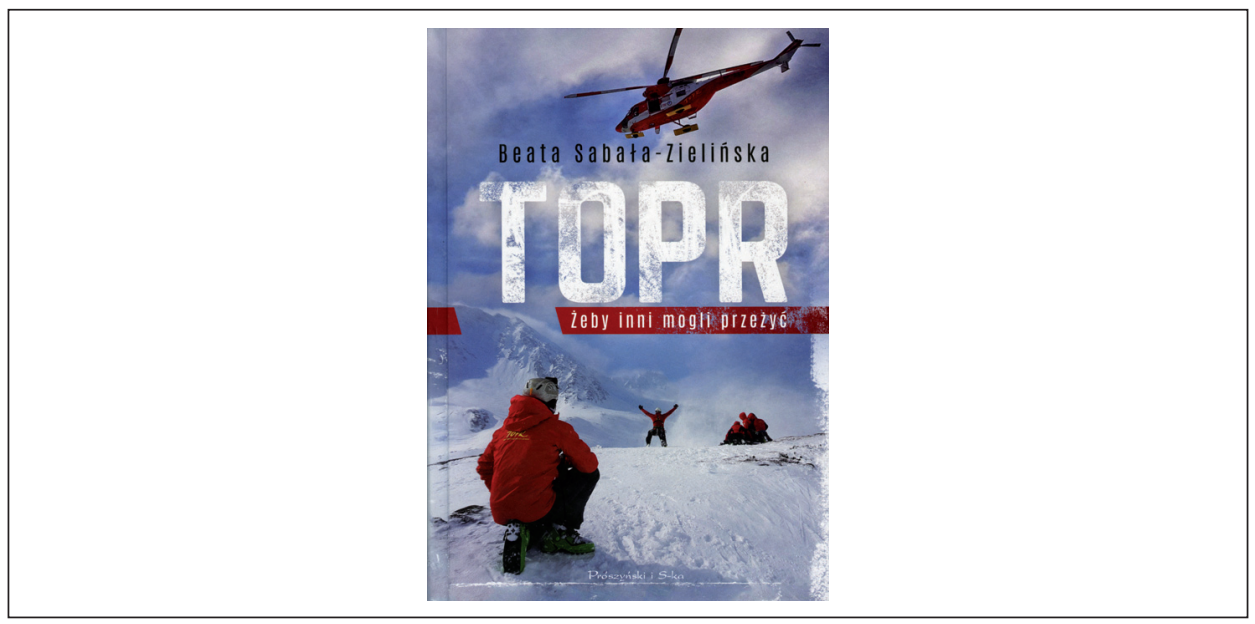

\title{
Na każde wezwanie naczelnika
}

DOI: 10.19195/2084-4107.12.29

[rec.:] Beata Sabała-Zielińska, TOPR. Żeby inni mogli przeżyć, Prószyński i S-ka, Warszawa 2018, ss. 352.

At the commander's every beck and call

Słowa-klucze: Tatry, TOPR, ratownictwo górskie, historia, region

Keywords: Tatra mountains, mountain rescue, Tatra Mountain Volunteer Search and Rescue, history, region

Beata Sabała-Zielińska jest dziennikarką mieszkającą w Kościelisku, autorką książek popularyzujących Podhale (napisanych wspólnie z Pauliną Młynarską: Zakopane odkopane i Zakopane. Nie ma przebacz oraz samodzielnej publikacji o pracy radiowej dziennikarki Radio-aktywna Sabała), a także wywiadu rzeki z nieżyjącą już Ewą Dyakowską-Berbeką, żoną Macieja Berbeki, który w 2013 roku zginął na Broad Peak (Jak wysoko sięga miłość? Życie po Broad Peak). Jej najnowsza książka o historii polskiego ratownictwa górskiego w Tatrach, w której wykorzystano narrację członków TOPR-u, to - jak sama autorka pisze we wstępie - „pierwsza tego typu publikacja w Polsce. Nigdy wcześniej ratownicy nie zdecydowali się tak otwarcie rozmawiać, zostaliśmy więc wyróżnieni tym zaproszeniem do hermetycznego świata górskich herosów" (s. 9).

Nie bez znaczenia jest to, że wszystkie dotychczasowe publikacje Sabały-Zielińskiej miały na celu popularyzację regionu, pretendując przy tym do rangi swoistych kompendiów wiedzy, opisujących historię i kulturę góralszczyzny cykl Zakopane... napisany wspólnie z Młynarską adresowany jest do odbiorców, 
którzy o specyfice Zakopanego i całego Podhala wiedzą mało lub nic. Można odnieść wrażenie, że TOPR kontynuuje tradycję zwracania się do szerokiego kręgu czytelników niekoniecznie obeznanych z Tatrami i Zakopanem, autorka bowiem skrupulatnie przedstawia podstawowe informacje, na przykład dane dotyczące wysokości szczytów („Nasz najwyższy szczyt - Rysy - ze swoimi 2499 metrami nad poziomem morza", s. 121) czy powierzchni, jaką zajmują polskie Tatry („Sto siedemdziesiąt pięć kilometrów kwadratowych polskiej części [...] i 75 kilometrów grani głównej”, s. 121).

Oczywiście, przy okazji rozważań na temat książki o tatrzańskich ratownikach nie sposób nie wspomnieć kultowego Wołania w górach Michała Jagiełły, którego ostatnie wydanie z 2012 roku osiągnęło objętość ponad 800 stron. Jagiełło jednak - jako wieloletni ratownik, a przez dwa lata również naczelnik TOPR-u - wypadki i akcje ratunkowe w Tatrach opisywał „od środka”, z perspektywy TOPR-owca. Tymczasem Sabała-Zielińska przyjmuje postawę zbliżoną do czytelniczej - jest laiczką, amatorką, która o górskim ratownictwie, przynajmniej od strony praktycznej, wie niewiele. Ta nieco inna perspektywa w zderzeniu z rozbudowanymi wypowiedziami samych ratowników pozwala na świeże spojrzenie na tatrzańskie pogotowie.

Ważne jest przy tym, że Tatrzańskie Ochotnicze Pogotowie Ratunkowe to jedna z nielicznych polskich organizacji, której postrzeganie jest przeważnie pozytywne. Postawa ratowników kładących na szali własne życie i bezpieczeństwo, by - przeważnie w czynie społecznym, a nie zawodowo - ratować turystów, zasługuje bowiem na uznanie i szacunek. W tym kontekście wiele kontrowersji wzbudzają — zwłaszcza w ostatnich latach, czyli z jednej strony okresie egalitaryzacji tatrzańskiej turystyki, a z drugiej intensyfikacji medialnego nią zainteresowania - niefrasobliwe postawy turystów odwiedzających Tatry, którzy albo podejmują się niełatwych górskich wyzwań bez przygotowania, albo niewymagające szlaki postrzegają jako przeszkody nie do pokonania.

Wydaje się zatem, że publikacja Sabały-Zielińskiej ma służyć dwóm celom: pokazaniu trudnej codzienności ratowników, którzy narażają się dla innych, oraz edukacyjnemu napiętnowaniu niekompetencji turystów. Opowieść o ratownikach TOPR-u autorka rozpoczyna rzeczowo: od przedstawienia drogi kandydata na ratownika TOPR-u do objęcia przez niego stanowiska, co przeplata wypowiedziami czynnych ratowników. W książce nie zabrakło również rysu historycznego, prezentującego początki polskiego ratownictwa górskiego ze szczególnym uwzględnieniem zasług jego wybitnych twórców i inicjatorów - generała Mariusza Zaruskiego oraz Klimka Bachledy, następnie powojennej historii przemianowania TOPR-u w GOPR i jego rozwoju aż po odzyskanie pierwotnej tożsamości i pełnej autonomii TOPR-u po 1989 roku. W głównych partiach książki zostały opisane nie tylko spektakularne, nagłaśniane przez media wypadki i zdarzenia w Tatrach (na przykład tragedia licealistów z Tychów, którzy zginęli w lawinie pod Rysami w 2003 roku, oraz ,zagubienie się” turystów w okolicy Morskiego Oka w okresie 
sylwestrowym 2015 roku), lecz także mniej znane, poruszające, a czasem komiczne epizody z życia zawodowego ratowników TOPR-u.

Co ważne, Sabała-Zielińska omawia również te aspekty ratownictwa tatrzańskiego, z którymi TOPR rzadko jest kojarzony i o których się zapomina, takie jak ratownictwo jaskiniowe oraz nurkowe.

Kompozycja książki ma charakter klamrowy — początkowe partie oraz zakończenie skupiają się wokół TOPR-u jako organizacji; mówi się tam o rekrutacji, wewnętrznych problemach (natury finansowej bądź organizacyjnej), wreszcie o obecności kobiet w TOPR-ze (rozdział ważny w dobie społecznej emancypacji problematyki kobiecej w kontekście gór, choć może nieco zbyt krótki i powierzchowny, stanowiący jedynie aneks do monumentalnej opowieści o mężczyznach-górskich herosach). Najobszerniejsza część książki, dotycząca ratownictwa ścianowego, lawinowego, jaskiniowego i nurkowego, zawiera urozmaicony wybór opowieści, anegdot oraz relacji z dramatycznych, czasem groteskowych wypadków i związanych z nimi akcji ratunkowych w Tatrach, spisanych na podstawie ustnych przekazów samych ratowników i opatrzonych uzupełniającymi komentarzami autorki. Wśród nich zdarzają się także wypowiedzi ofiar górskich wypadków - Kasi uratowanej z lawiny w Świstówce w 2015 roku czy Stefana Stefańskiego, czekającego przez tydzień w Ptasiej Studni na pomoc — którzy opisują akcje TOPR-u z własnej perspektywy poszkodowanych.

Dużą zaletą publikacji jest jej diachroniczność — autorka nie porusza wyłącznie tematów bieżących, ale cofa się w przeszłość, zarówno do początków TOPR-u, kolejnych etapów jego rozwoju (gdy ratownicy zdobywali nowe umiejętności, udoskonalali swój ekwipunek), jak i konkretnych wypadków historycznych w Tatrach — czasem bardzo znanych (lawina w Żlebie Marcinowskich w 1956 roku), czasem zapomnianych. Sięga też do wielu źródeł, czerpie ze wspomnień świadków, ale i ubarwia narrację dowcipną puentą czy obserwacją, nierzadko wykorzystując swoją dziennikarską praktykę, która przez lata pozwalała jej przyglądać się szkoleniom TOPR-owców.

Nieco kontrowersyjny i dezorientujący wydaje się jednak wydźwięk niektórych fragmentów książki, szczególnie rozdziału To przykre, straszne i zawstydzające, poświęconego kwestii wynagrodzeń dla TOPR-owców i ignorowaniu tego problemu przez kolejne partie rządzące. Choć sam postulat godnego wynagradzania górskich ratowników jest bez wątpienia słuszny, to eksponowanie tego problemu w książce o charakterze popularyzatorskim i reportażowym nadaje jej cechy publicystyki, co wprowadza swego rodzaju dysonans i nasuwa pytania o intencje Sabały-Zielińskiej.

Kolejnym niedopatrzeniem, choć być może zamierzonym, jest nieprzedstawienie wśród licznych wypowiedzi ratowników perspektywy ich rodzin: partnerek, dzieci, najbliższych. Autorka oddaje im głos jedynie przy okazji opisywania tragedii pod Szpiglasową Przełęczą z 2001 roku, podczas której zginęli ratownicy: Marek „Maja” Łabunowicz oraz Bartek Olszański. Wdowa po „Mai” i matka 
Olszańskiego skupiają się jednak wyłącznie na stracie swoich najbliższych, zaznaczając przy tym, że nie mają do nikogo pretensji o ich śmierć. Taka perspektywa — tych „,czekających”, a nie uczestniczących w akcji — która pojawia się we wspomnianym wywiadzie rzece z Ewą Dyakowską-Berbeką, mogłaby wzbogacić publikację. Tymczasem rodziny ratowników górskich wspominane są jedynie kontekstowo, a przy tym dość stereotypowo, jako te „ograniczające”: „Jadą do Morskiego Oka około dwudziestej, a do domów wracają o drugiej, bojąc się, że któregoś dnia wkurzone żony wystawią im walizki za próg" (s. 300).

Publikacja Sabały-Zielińskiej zasługuje na uwagę, gdyż stanowi nie tylko cenne i potrzebne źródło wiedzy na temat działalności tatrzańskich ratowników, lecz jest także złożonym im hołdem (co podkreśla sama autorka). Choć podczas lektury książki nasuwają się czasem obawy o nadmierną, odzierającą ze zwykłego człowieczeństwa mitologizację TOPR-owców, to korzyści, które mogą płynąć z lektury, wydają się o wiele większe — i to nie tylko dla ludzi gór.

Anna Pigoń

ORCID: 0000-0002-3098-1888 